\title{
PRISONERS' RIGHTS UNDER THE NIGERIAN LAW: LEGAL PATHWAYS TO PROGRESSIVE REALIZATION AND PROTECTION
}

\author{
Marcus Ayodeji Araromi*
}

\begin{abstract}
prisoner is denied certain rights as a result of the custodian judgment 1 passed on him or her by a court of law. A prisoner in custody is specifically subjected to restraint of movement and can, therefore, not have total assurance of enjoyment of the freedom of personal liberty under the law. Be that as it may, a prisoner who is observing the sentence of court by being in custody does not totally lose his rights as a human being and must, therefore, enjoy some basic rights despite being confined to prison. In reality, prisoners are seen as being less of human beings and are not well treated when observing custodian sentence. Some rights are denied the prisoners by the prison administrators and, by extension, the State by lack of will to promote enabling environment and treatment to the prisoners. It is against this backdrop that this article appraises prisoners' rights that are to be respected, protected and fulfilled under the law, at national, regional and international levels. The article argues that there are certain essential and set global standards for the treatment of prisoners, which are not currently followed in prison administration in Nigeria. This article examines basic fundamental human rights which should not be forfeited as a result of incarceration. It evaluates how such rights fare in the Nigerian prison system, and itemizes practical measures that must be put in place to ensure the protection and fulfilment of these rights in Nigeria.
\end{abstract}

Keywords: prisoners, human rights, health, liberty, freedoms. doi: http://dx.doi.org/10.4314/jsdlp.v6i1.8

* Senior Lecturer, Department of Public Law, Faculty of Law, University of Ibadan; email address: demarc007@hotmail.com, phone no: 08052236247. 


\section{INTRODUCTION}

$\mathbf{R}$ ight is a generic term that confers certain benefits on a person who R possesses it. Generally, right, as a matter of fact, can be innate and naturally endowed by virtue of being human; it can also be derived by the operation of law. ${ }^{1}$ There are basic rights which are both naturally given and protected in the letters and spirit of the law. ${ }^{2}$ Some of these rights are regarded as very fundamental to human existence and therefore should not be deprived except in circumstances provided for by the law. Some rights are also given international recognition because they are so important that they have to be addressed at the global level to appropriately secure such from being trampled upon, and for their observance and effective implementation. ${ }^{3}$ Before the 1960s, in the United States, a prisoner was seen not only to have forfeited his liberty as a result of crime, but also all his personal rights except those that the law of humanity accords to him; and a prisoner was thus regarded as a slave

1 See M. Cranston, What are Human Rights? (Taplinger Publishing Co., 1973), 36; also E. Kamenka, "Human Rights, Peoples' Rights" in J. Crawford (ed.), The Rights of Peoples (Oxford University Press, 1988), 127; J. Shestak 'The Philosophical Foundations of Human Rights' in J. Symonides, Human Rights Concepts and Standards (England; Burlington Vt: Ashgate, 2000), 33-35.

2 See R. Hittinger, "Natural Law and Virtue: Theories at Cross Purposes" published in R. George (ed.), Natural Law Theory Contemporary Essays (Oxford University Press, 1994), 63; See also R. Wacks, Understanding Jurisprudence: An Introduction to Legal Theory (Oxford University Press, 2005), 15; R. George, "Natural Law", Harvard Journal of Law and Public Policy, 31(1) (2008), 171-96; N. Ferreira, “The Expanding Realm of Human Rights", Res Publica, 14 (2008), 57; Shestak "The Philosophical Foundations of Human Rights" (n 63), 33-35.

3 There are ten core international human rights instruments: International Covenant on Civil and Political Rights, Dec. 19, 1966, 999 U.N.T.S. 171 (hereinafter ICCPR); the International Covenant on Economic, Social and Cultural Rights, Dec. 16, 1966, 993 U.N.T.S. 3(hereinafter ICESCR); the International Convention on the Elimination of All Forms of Racial Discrimination, Mar. 7, 1966, 660 U.N.T.S. 195 (hereinafter CERD); Convention on the Elimination of All Forms of Discrimination against Women, Dec. 18, 1979, 1249 U.N.T.S. 13 [hereinafter CEDAW]; Convention against Torture and Other Cruel, Inhuman or Degrading Treatment or Punishment, Dec. 10, 1984, 1465 U.N.T.S. 85; Convention on the Rights of the Child, Nov. 20, 1989, 1577 U.N.T.S. 3; International Convention on the Protection of the Rights of All Migrant Workers and Members of Their Families, Dec. 18, 1990, 2220 U.N.T.S. 3; the Convention on the Rights of Persons with Disabilities, Dec. 13, 2006, U.N. Doc. A/61/611. See OHCHR, "Core International Human Rights Instruments", www.ohchr.org/EN/ ProfessionalInterest/Pages/CoreInstruments.aspx, accessed 12 March 2015. 
of the State. ${ }^{4}$ It was in the 1960s and 1970s that the court began to extend constitutional protection to prisoners. ${ }^{5}$

Courts may confine offenders to prison terms, which ordinarily deprive them of certain freedoms that should be enjoyed if not for the order or pronouncement of the court; such rights include most importantly freedom of movement. Therefore, the prisoners are not precluded from enjoying certain rights as entrenched in the Constitution and other legal documents, which are to be enjoyed by the citizens. This paper, therefore, focuses on the rights of prisoners. The Constitution, local statutes and international instruments protect certain rights that should be available to the prisoner. Gradually, the philosophy of imprisonment is now shifting from using it as a tool of retributive justice to reformation, with the hope of reforming prisoners and absorbing them back into the society as better citizens. It is against this philosophy that prisoners need to be treated as the human beings that they are and should not be subjected to degrading and inhuman treatment which could make them embittered and go back to the society with wounded psyche which will make the society the worse for it.

Accordingly, the prison community, with its culture and way of life, gives a complete design capable of changing the attitudes of the offenders for good or bad depending on the personal experience of the prisoners and the social network action. ${ }^{6}$ It is an acceptable fact that operations and administration of the prison system in Nigeria turn the less hardened individuals to more hardened criminals when unleashed to the society due to their experience through the prison. ${ }^{7}$ The fundamental cause of post-release problem of maladjustment and recidivism is traceable to the lock-up pattern and content of the prisons. ${ }^{8}$

Sentencing a convict to a prison term is meant as punishment and not for punishment; therefore, prison authorities have to be accountable for

4 This approach was referred to as "hands-off doctrine" protecting the state and prisons officials from judicial condemnation. See Gary Rock (2009) “Prisoner's Rights Handbook 1" (Angus Love ed. Pa Institutional Law Project).

5 See Wolff v. McDonnell, 418 U.S. 539, 555 (1974).

6 Chukwudi, F, "Challenges of Reforms in the Nigerian Prison System: Lessons From U.S.A. and South Africa” (2012) Vol. 4 Journal of Social Science and Public Policy, 36.

7 Adetula, G. A. and Fatusin, A. F, “The Prison Subsystem Culture: Its Attitudinal Effects on Operatives, Convicts and the Free Society" (2010) Vol. 18, No. 1. Psychological 232-251.

8 Chukwudi, F (n 6). 
the manner prisoners are treated, especially regarding their wide discretional powers. ${ }^{9}$ The Nigerian Court of Appeal held per Uwaifo, JCA in the case of Peter Nemi v Attorney General of Lagos State and Ors ${ }^{10}$ that prisoners still have their rights intact, except those deprived by law. He stated further that even a condemned criminal awaiting execution still maintains his rights until properly executed by the due process of law. However, this is not the case in Nigeria, as prisoners are not treated well in prison. The prison officials and administrators truncate many of prisoners' human rights. It was reported by the National Human Rights Commission of Nigeria, for instance, that there have been a lot of human rights challenges in the Nigerian prisons and the situation of the inmates is quite appalling. According to the Commission:

The prison environment continues to pose serious threats to the physical and mental well-being of inmates and prison officers alike. Conditions such as overcrowding, lack of medical/health facilities, poor toilet facilities and beddings, and denial of access to justice continues to persist in clear contrast to the requirement of the UN standards for the treatment of persons in Custody. This state of affairs is attributable to action and/or inactions of all players in the administration of justice sector in Nigeria. ${ }^{11}$

The Commission also made an observation that the Federal Government has failed to implement the recommendations of many studies carried out on the prison situation in Nigeria and by presidential committees, and has done only little in fulfilling its promises over the years, which has contributed immensely to the challenges being faced by the prison system. ${ }^{12}$

The European Convention on Human Rights (ECHR) by Article 14 guarantees everyone in the State equal access to rights, without discrimination. The practice of the ECHR has moved away from supporting inherent limitations to the rights of incarcerated prisoners (i.e., deprivation of liberty automatically means loss of other rights and

9 Jon Vagg. Prison System- A Comparative Study of Accountability in England, France, Germany and the Netherlands, Clarendon Press, Oxford 1994.

10 (1996) 6 NWLR (Pt 452), 42.

11 National Human Rights Commission Nigeria Report of Prison Audit, 2009, p. 129. It should be noted that the prison condition has not changed in the 2012 Prison Audit Report of the Commission.

12 ibid. 
freedoms) to a more liberal approach and wider protection of fundamental human rights during imprisonment. It is viewed that international human rights standard states that prisoners should continue to enjoy access to all rights guaranteed to all persons in the State, "subject only to restrictions that are unavoidable, necessary and appropriate in the context of imprisonment." 13

Rule 2 of the European Prison Rules (2006) also states, “persons deprived of their liberty retain all rights that are not lawfully taken away by the decision sentencing them or remanding them in custody." Similarly, the United Nations Human Rights Committee provides in its General Comment No. 21 that respect for the dignity of such persons deprived of their liberty must be guaranteed under the same conditions as for that of free persons. It goes further that, such persons shall enjoy all rights set forth in the Covenant, subject to the restrictions that are unavoidable in a closed environment. ${ }^{14}$

Section 19 of the Prisons Act defines a "prisoner" as any person lawfully committed to custody. ${ }^{15}$ By this definition, it means any person who is lawfully confined to prison is a prisoner. This, therefore, means that a person becomes a prisoner on the date first admitted into prison, which therefore qualifies Awaiting Trial Inmates as prisoners because they are normally confined to prison by the order of the court. ${ }^{16}$ Pre-trial detention itself does not violate human rights if it takes place under the proper conditions, for a short time and as a last resort. ${ }^{17}$ Prisoner's rights can be divided into two categories, which are prisoner's rights before conviction and prisoner's rights after conviction. ${ }^{18}$ This article focuses on the latter, the rights of the prisoner after conviction.

13 Irish Penal Reform Trust Position Paper 4, Human Rights in Prison, August 2009 , p. 4.

14 United Nations Human Rights Committee (1992) General Comment No. 21 Replacing General Comment 9 concerning humane treatment of persons deprived of liberty (Art. 10); 10/04/92.CCPR General Comment No. 21. Available at $<$ www.unhchr,ch/tbs/doc $>$

15 Prisons Act Cap. P29, Laws of the Federation of Nigeria (LFN), 2004.

16 See Edmund Okoro E Ors v. Minister of Internal Affairs E Ors (Unreported) Suit No. FHC/EN/CP/102/2000.

17 Jeremy Sarkin, "Prisons in Africa: An Evolution from a Human Rights Perspective” Legal Studies Research Series, Research Paper No. 09-13, p.5 or Sur International Human Rights Journal (2009) Vol. 9, 22-49.

18 Olokooba, S. M. and Oyedokun-Alli, W.A, "An Overview of the Rights of the Prisoners under the Nigerian Law." Confluence Journal of Jurisprudence and International Law, 136. 
This article is divided into four sections. After this general introduction; section 2 appraises the conditions of persons in Nigerian prisons; section 3 evaluates the rights open to Nigerian prisoners and how the law protects such rights; the last section contains conclusion and recommendations on legal frameworks required for a more effective protection and fulfilment of prisoners' rights in Nigeria.

\section{APPRAISING THE CONDITIONS OF PERSONS IN PRISON}

The Constitution of the Federal Republic of Nigeria confers certain rights on the citizens and, most importantly, Chapter IV of the document protects certain rights that are regarded as fundamental to human existence. A prisoner, just as any other Nigerian, is ordinarily entitled to the fundamental rights entrenched in the Constitution. Some of these rights include:

a. Right to life ${ }^{19}$

b. Right to dignity of human person; ${ }^{20}$

c. Right to fair hearing, ${ }^{21}$

d. Right to private and family life; ${ }^{22}$

e. Right to freedom of thought, conscience and religion; $;^{23}$

f. Right to freedom of expression and the press; ${ }^{24}$

g. Right to peaceful assembly and association; ${ }^{25}$

h. Right to freedom from discrimination; ${ }^{26}$ and

i. Right to acquire and own immovable property anywhere in Nigeria. ${ }^{27}$

Except in circumstances provided by the Constitution the above rights are inalienable and cannot be deprived. For instance, Section 33 which

19 See section 33 of the 1999 Constitution.

20 ibid section 34 .

21 ibid section 36 .

22 ibid section 37.

23 ibid Section 38.

24 ibid Section 39.

25 ibid Section 40.

26 ibid Section 42.

27 ibid Section 43. 
deals with right to life provides that no one shall be deprived of his life intentionally except in execution of the sentence of a court in respect of a criminal offence of which he has been found guilty in Nigeria. ${ }^{28}$ Also, Section 34 of the Constitution ensures the dignity of human person and, therefore, no one should be subjected to torture or to inhuman or degrading treatment, nor be subjected to slavery or servitude, and no one shall be required to perform forced or compulsory labour, save any labour required in the consequence of the sentence or order of a court among other exceptions.

Right of prisoner to privacy may be subject to subversion, as a prisoner has no reasonable expectation of absolute privacy in his cell. It is reasonably expected that a prisoner should be subjected to constant and thorough search while in prison so as to prevent concealment of objects that are forbidden for prisoners such as weapons, drugs, and other contrabands. ${ }^{29}$

The fact that a prisoner is serving a prison term does not debar him from owning property. This right is guaranteed under the Section 44 of the Constitution but such right can be invaded by the provisions of any general law for the imposition or enforcement of any tax, rate or duty; ${ }^{30}$ for the imposition of penalties or forfeiture for the breach of any law; ; $^{31}$ or relating to the execution of judgments or orders of court, among other conditions stipulated under that section.

Generally speaking, those who are put into prison in Nigeria are confined in a congested and dirty environment, with insufficient provision of food, inadequate hygiene, and lacking in basic amenities. ${ }^{32}$ It is quite informative that most of the prisons in Africa, including Nigeria, are facing

28 ibid Section 33(1).

29 For instance, section 14 of the Prisons Act provides that it is an offence to bring, throw or otherwise introduce into or remove from a prison, or give to or take from a prisoner, any alcohol, liquor, tobacco, intoxicating or poisonous drug or article prohibited by regulations made under this Act. See also Regulation 3 of the Prisons Regulations L.N. 11955 (a Subsidiary Legislation made under the Prisons Act).

30 Section $44(2)(a)$ of the Constitution.

31 ibid section 44(2)(b).

32 See the Executive Summary of 2012 Prison Audit by the National Human Rights Commission and Other Stakeholders. See also Sabella Abide "Prisons and Human Rights Abuses in Nigeria”, Punch, 26 March 2014, available at $<$ www.punchng.com/opinion/viewpoint/prisons-and-human-rights-abuses-innigeria-part-1/> 
a host of challenges ranging from poor governance, inadequate funding, lack of political will, faulty criminal justice system, among others, which have led to overcrowding of prison facilities and other abusive prison conditions. ${ }^{33}$ Prison brutality can be traced to the racist and colonial heritage of the late 1800s, and it is still the norm after the departure of the colonial masters that penal oppression persists at an alarming rate in Africa. ${ }^{34}$ The prison culture is mottled with overcrowding, lack of infrastructure, corporal and capital punishment, extended awaiting trial detention, corruption, inadequate attention to women and youth, and such other negative conditions associated with the prison system. ${ }^{35}$

Some common problems in the prison facilities in Nigeria are that most of the prisons are old, poorly ventilated, and lack sleeping space, food, medical care and sanitary conditions. These can encourage poor health condition and easy spread of communicable diseases. Inadequate recreational facilities, vocational and rehabilitation programmes, are other unfavourable conditions of the Nigerian prison system. ${ }^{36}$ The prisons audit taken by the National Human Rights Commissions in 2012 shows that most of the prisons in Nigeria are old and dilapidated with some built as far back as the 18th century during the native rules; with poor sanitary conditions, no recreational, vocational facilities or infrastructure. It was reported also that the health facilities, educational facilities, sources of water and energy are more or less non-existent or at their lowest ebb. With the 173 prisons of total capacity for 46,024 inmates audited in Nigeria by the Commission, it was shown that a total of 50,645 inmates were locked up in the prisons with the Awaiting Trial detainees far outnumbering the convicted prisoners, leading to congestion. ${ }^{37}$ The bed and bedding facilities were also reported to be inadequate and some of the inmates had to sleep on the bare floor in poorly ventilated cell rooms. The toilet facilities leave much to be desired as they are poorly maintained; the inmates are poorly fed with official feeding allowance of 200 Nigerian Naira (NGN) per day.

While the prison environment remains unsuitable, little or nothing is being done to ameliorate the conditions of the women and children who

33 Jeremy Sarkin, "Prisons in Africa: An Evaluation from a Human Rights Perspective” (2009), Vol. 9, Sur International Human Rights Journal 2.

34 ibid 4.

35 ibid.

36 See the National Human Rights Commission Nigeria Report of Prison Audit, 2012.

37 ibid. 
are considered vulnerable groups. One of these maladies is lack of adequate facilities to accommodate women undergoing menstruation who are sometimes exposed to physical and psychological abuse from the prison guards or put in prison among men. ${ }^{38}$ Part of the reasons behind incarceration of offenders is to rehabilitate and reintegrate them back into the society. After visiting and comparing the nature of treatments given to prisoners in some prisons in the United States, the Netherlands, and Israel Dervan makes a general submission that:

Where prisoners believed they were treated like human beings and were provided with reasonable living conditions and opportunities to utilize their time in meaningful ways, the prison environment was relatively healthy and rates of violence were low..., where prisoners were subjected to abhorrent living conditions and no efforts were made to treat them with a modicum of respect or provide them with even a scintilla of meaningful stimulation during the day, the prison environment was poised and violence ran rampant. ${ }^{39}$

At this juncture, some rights, which are very important and should be enjoyed by prisoners directly or by extension are going to be considered.

\section{RIGHT TO PROTECTION AND PROVISION FOR THE CHILDREN OF INCARCERATED PARENTS}

Incarcerating parents of minors can also have its negative toll on such children as it can expose the children to harm in the society, and also from those who stand in as caregivers. ${ }^{40}$ It is imperative to state that the children of confined prisoners, like any other child, are entitled to enjoy certain rights which should not be denied based on the circumstances of

38 Jeremy Sarkin (n 33) 13-14.

39 Dervan, Lucian E, “American Prison Culture in an International Context: An Examination of Prisons in America, The Netherlands, and Israel” (2011) Vol. 22:2 Stanford Law and Policy Review, 426.

40 Chesa Boudin, "Children of Incarcerated Parents: The Child's Constitutional Right to the Family Relationship” (2011) Vol. 101, No. 1, The Journal of Criminal Law and Criminology 77. 
their parents' misbehaviour. They are entitled to enjoy family life and care. Even where they are given the opportunity to visit their incarcerated parents there may not be any assurance of care for their needs in the absence of their parents. Article 18(2) of the African Charter on Human and Peoples' Rights which is also applicable to Nigeria put it upon the State parties to assist the family which is the custodian of morals and traditional values recognized by the community. ${ }^{41}$

Moreover, the African Charter also imposed a duty on every individual "to preserve the harmonious development of the family and to work for the cohesion and respect of the family." 42 The family serves as an essential fabric of the society and it is therefore important to keep the family together in love and peace and provide for its needs to help in bringing cohesion in the society. The children are the most vulnerable of the family and that need to be catered for morally and financially. If the parent of a child is imprisoned, it is important that the State looks into the welfare of such a child so that he/she will not become a fiend to the society.

There are no existing policies, nor is there a specific legislative mechanism in Nigeria to protect this vulnerable group from endemic plights suffered for no mistakes of theirs, but by merely being victims of circumstances. Against the backdrop of the existing policy approach in Nigeria, the right of the children of incarcerated parents can be reviewed under international instruments which are the Convention on the Rights of the Child (CRC) ${ }^{43}$ and the African Charter on the Rights and Welfare of the Child, ${ }^{44}$ which Nigeria is signatory to. The CRC was developed without any direct application to the children of incarcerated parents but creates a "strong legal basis for a child-oriented approach to sentencing and visitation policy." 45 There may seemingly be a slight conflict between the provision of the CRC which recognizes the right of the child "to know and be cared for by his or her parents" ${ }^{\prime 6}$ and the societal interest for incarceration.

41 Article 18(2) of the African Charter on Human and Peoples' Rights, 1986.

42 See Article 29(1) of the African Charter on Human and Peoples' Rights.

43 Convention on the Rights of the Child, November 20, 1989.

44 African Charter on the Rights and Welfare of the Child, November 29, 1999.

45 Chesa Boudin (n 37) 84.

46 See art. 7(1) of the CRC. 
Article 9 of the CRC guarantees the right of a child who is separated from his or her parent(s) to maintain personal relations and contact with such parent(s) on a regular basis except such is contrary to the child's interests. Interests of the child may appear to be vague and subject to different interpretations. Various factors may need to be considered to determine what the interest could be. Among other factors, condition of the prison facilities would determine if visitation to incarcerated parent is contrary to the interests of the child. If, for instance, the arrangement in the prison is not child protective it may not be in the best interest of such a child to be exposed to such situation to avoid recidivism. Or, if contact with the incarcerated parent will be a bad influence on the child, it may be necessary to shield the child from such contact.

The African Charter on the Rights and Welfare of the Child is more focused on the right of the child through incarcerated mother, especially where such mother falls within the genus of lactating or pregnant mothers. The Charter ensures the provision of specific treatment to expectant mothers and to mother of infants and young children and to ensure that non-custodial sentence will be first considered when sentencing the mothers. ${ }^{47}$ The Charter also considers the plight the children of convicted mothers might pass through due to the type of sentence imposed on such mothers. It further encourages the State parties to avoid imposition of the death penalty on such mothers. ${ }^{48}$

\subsection{Prisoner's Right to Vote}

Right to participate freely in government of one's country, either directly or through representatives, is a provision entrenched in the African Charter on Human and Peoples Rights. ${ }^{49}$ By and large, there is no gainsaying that when a person is incarcerated it does not mean that he has forfeited all the rights that are legally accruable to him. A prisoner need not be disenfranchised by the mere fact that he is incarcerated. Many policy decisions by a government may equally affect the prisoners as they affect the free citizens. Therefore, a prisoner should also be given the right to elect the rightful leaders that he believes will promote his cause.

47 See article 30 of the African Charter on the Rights and Welfare of Children.

48 Article 30 of the African Charter on the Rights and Welfare of Children.

49 Article 13(1) of the African Charter on Human and Peoples' Rights, 1986. 
No law in Nigeria has positively excluded prisoners from participating in elections through voting. There was hardly any time during the past election exercises where prisoners in Nigeria were given adequate consideration to exercise their franchise, and a case for the determination of this right had never gone to court. This same problem of disenfranchisement of prisoners is evident in many jurisdictions and it has become a topical issue that has engaged the attention of scholars, human rights activists, lawyers, and other actors in the socio-political milieu, especially in Europe. It is therefore germane to review the need for the exercise of this right under the dispensation of the jurisdictions in Europe, especially the United Kingdom, who has taken a journey into the jurisprudential need of ensuring the protection of such right.

In the United Kingdom, for instance, the issue of blanket ban on prisoners' right to vote has come to be determined by the court. The English statute, Representation of the People Act 1983 provides in Section 3(1) that a convicted person who is serving a prison term in a penal institution in pursuance of his sentence is legally incapacitated to vote at any parliamentary or local government election. It was the belief of the British government that imprisonment after conviction makes such prisoners forfeit certain rights beyond the right to liberty, and especially on the basis that voting is a privilege and not a right. ${ }^{50}$ It was argued in Hirst's case that disenfranchising prisoners "took away civic responsibility and eroded respect for the rule of law, serving to alienate prisoners further from society." 51 The European Court of Human Rights Grand Chamber held that the provision of the Representation of the People Act constituted an infringement of Article 3 of Protocol 1 of the European Convention on Human Rights (ECHR).

Parliament's Joint Committee on Human Rights (JCHR) in 2008 claimed that Hirst's case provided "clear guidance that individuals' fundamental human rights, including the right to vote are not contingent on their continuing to be 'good citizens'." ${ }^{2}$ In Scotland, many cases

50 Hirst v. United Kingdom (No. 2), App. No. 74025/01 (2006) 42 EHRR 41. This case was decided by the European Court of Human Rights' Grand Chamber.

51 ibid.

52 JCHR, Third Report of 2007-2008, Monitoring the Government's Response to Human Rights Judgments: Annual Report 2008 (7 Oct. 2008) HL Paper 173/ HC 1078, [58]. Cited in Murray, C. R. G. "We need to talk: 'Democratic Dialogue' and the ongoing saga of prisoner disenfranchisement," accessed on the March 13, 2015 from <ttp://ssrn.com/abstract=1718984> 
erupted as to the determination of the right of prisoners to vote in elections. In the case of Smith, the court made a declaration that Section 3 of the Representation of the People Act 1983 was in breach of the ECHR. ${ }^{53}$

In the United Kingdom where the issue of prisoners' right to vote has for a number of years remained on the front burner, there is a great measure of reluctance on the part of the judiciary to freely accord the prisoners right to vote in elections. For instance, in $\operatorname{Re} S$ (Minors) $)^{54}$ Lord Nicholls held that re-interpreting Section 3 of the Representation of the People Act so as to allow any prisoners the right to vote would depart substantially from a fundamental feature of the legislation and this would be tantamount to court legislating on its own. ${ }^{55}$ The domestic courts in the United Kingdom, after the decision in Hirst, had adopted the culture of rejecting the argument that the Grand Chamber's decision mandated particular reform in the domestic laws and therefore ruled out judicial solution to the problem of disenfranchisement of prisoners.

Article 3 of Protocol No.1 of the European Convention does not prevent placing restrictions on electoral rights, which could be placed on individuals depending on the nature of their offence. For instance, a prisoner who has seriously abused a public position or whose conduct threatened to undermine the rule of law or democratic foundations may be prevented from voting. ${ }^{56}$ In Hirst's case earlier cited, the European Court of Human Rights held that there had been violation of Article 3 of the Protocol No.1 to the European Convention on Human Rights due to automatic and discriminate restriction on the applicant's right to vote as a convict. Also, in the latter case of Greens and MT $\mathrm{v}$ The United Kingdom, ${ }^{57}$ the Court's Grand Chamber in November 2010 found that the UK failed to execute its judgment in Hirst's case by making necessary amendments to its laws. The court therefore held that there had been a violation to Article 3 of Protocol no. 1 of the Convention in the instant case. The court further gave the United Kingdom government an ultimatum to make effective change to its legislation in line with Article 3 of the Protocol.

53 Smith [2007] CSIH 9, [27].

54 Case Order: Implementation of Care Plan [2002] UKHL 10, [40].

55 See also Chester v. Secretary of State for Justice and Another [2009] EWHC 2923 (Admin), [26].

56 “Prisoners' Right to Vote," European Court of Human Rights' Fact Sheet, February 2015, p. 2.

57 Greens and M.T. v. The U.K. (application nos. 60041/08 \& 60054/08). 
However, in the later decisions of the court it was revealed that the United Kingdom had taken decisive steps to actualize the provision of Article 3 of the Protocol. In the case of Firth and Others v. The United Kingdom, ${ }^{58}$ ten prisoners were prevented from voting in elections to the European Parliament in 2009 due to their convictions and detention pursuant to the sentences of imprisonment. The court recognized the fact that the United Kingdom Parliament had drafted a bill in line with Article 3 of Protocol No.1 but there was yet no amendment to the law, and therefore violated that Article. ${ }^{59}$ In like manner, the European Court of Human Rights had similarly decided in cases from some other European States that Article 3 of the Protocol No.1 was binding and thus must be observed. ${ }^{60}$

The philosophy of giving prisoners right to vote is tilted towards having some exceptional categories of prisoners who should be allowed the right. Therefore, blanket application of disenfranchisement of all prisoners will not be good. In British Columbia province of Canada, remanded prisoners and prisoners serving sentence of less than two years have a right to vote in the provincial and federal elections. Moreover, such prisoners could also have voting rights in municipal elections. To ensure that the prisoners do not leave the precinct of the prison there are provisions for voting by proxy mobile polls or polls within the prison. ${ }^{61}$

Given that the judiciary may not want to take a radical step in pronouncing that the prisoners need to have a say in who to govern him, as evinced in the United Kingdom, it will be dignifying to have appropriate legislation in place to establish the fact that people under incarceration should not be subjected to blanket denial of voting right. This same view should constitute a rider to the Nigerian government in encouraging the exercise of the franchise of prisoners in Nigeria. Moreover, the right to

58 Application No. 47784/09.

59 See also McHugh and Others v. The United Kingdom (No. 51987/08).

60 See Frodiv. Austria (Application no. 20201/04) (bordering on an Austrian election in which prisoners were prevented from voting). See also an Italian based case of Scoppola (No.3) v. Italy (Application no. 126/05) where the court held, confirming the decision in Hirst's case that general, automatic and indiscriminate disenfranchisement of all serving prisoners, irrespective of the nature and gravity of their offences, is incompatible with Article 3 of Protocol No.1.

61 A Handbook on Prisoners' Legal Rights in British Columbia Provincial Prisons produced by Prisoners' Legal Services, A project of the West Coast Prison Justice Society, May 2011. 
participate freely in government, either directly or indirectly, is guaranteed under Article 13 of the African Charter on Human and Peoples' Rights. ${ }^{62}$

\subsection{Prisoner's Right to Health}

Section 4 of the Prisons Act, though acknowledges that a prisoner may be sentenced to prison with hard labour, gives a prisoner a measure of relief in case such a prisoner is not fit to carry out such labour as may be directed by the superintendent of the prison where the prisoner is confined. Section 4(3) of the Act provides that:

The medical officer may order any prisoner to be excused labour or to perform light labour, and any prisoner ordered to perform light labour shall be required to do work for which he is certified by the medical officer to be fit. ${ }^{63}$

In furtherance of the protection of the health right of prisoners, the Prisons Act also provides that the Director of the Nigerian Prison Service of the Federation, who shall have the general charge and superintendence of the prisons system in Nigeria, may, where it appears to him that by reason of the outbreak of disease within the prison, by order under his hand direct that so many of the prisoners as may be indicated in the order shall be kept and detained in a building or place which is outside the prison and is specified in the order until such order is cancelled. ${ }^{64}$ This is a laudable power being conferred on the director to assure safe health of prisoners in confinement. The extension of the power of the director under the same section of the Act is that the director may make order for removal of prisoners to a separate place where it appears to him that the number of prisoners in a prison is greater than can conveniently be kept there and that it is not convenient to transfer the excess number of prisoners to another prison. ${ }^{65}$

62 Article 13(1) of the African Charter on Human and Peoples' Rights provides that "Every citizen shall have the right to participate freely in the government of his country, either directly or through freely chosen representatives in accordance with the provisions of the law."

63 Cap P29 Laws of the Federation of Nigeria, 2004.

64 See section 5(2)(b) of the Prisons Act.

65 Section 5(2)(a) of the Prisons Act. 
In the two subsections instances mentioned above, where the director can order removal of prisoners to another place, such a place can be deemed to form part of the prison for the purpose of the Prisons Act until the order so made by the director is cancelled. ${ }^{66}$ Prison congestion has very far-reaching implications on the health of prisoners and, therefore, should not be encouraged. The power given to the director in section 5 of the Prisons Act seems not be effectively exercised as evidence shows that virtually all the prisons in Nigeria are full to capacity and heavily congested which could allow for outbreak of diseases, and eventual death of prisoners. ${ }^{67}$ This problem cannot be disconnected from the lack of political will by the government to establish more facilities to accommodate the surging number of prisoners in Nigeria. Even this power is hardly exercised to benefit common prisoners except the influential ones who have the necessary money and political power to plough their way through and enjoy relative convenience when in detention or serving prison term.

To further protect or salvage the health of prisoners, the Prisons Act also confers power on the Director, or the superintendent in case of emergency, to make an order on the certificate of the medical officer ${ }^{68}$ to direct the removal of a seriously ill prisoner confined in a prison to a hospital specified in the order where there is no suitable accommodation for him in the prison. ${ }^{69}$ This provision provides room for the recuperation of prisoners who are ill by seeking out for better health facilities for them. When a State deprives a person of his liberty, it should take on the responsibility of looking after his/her health in terms of the condition under which he/she is detained, and provide individual treatment, which

66 See section 5 of the Act.

67 See Agomoh, U, "Prison Decongestion and Reforms in Nigeria - Issues and Methods" <www.prawa.org > accessed 12 September, 2015. Also according to the investigation carried out by the Daily Independence News Paper about 56,785 inmates are presently languishing in 239 prisons across the country, out of which 18,042 representing 32 per cent are convicted prisoners, while about 38,743 inmates representing 68 per cent are Awaiting Trial Persons (ATP) therefore causing congestion in the prisons (Daily Independence "Urgent need for prison reforms in Nigeria". <http://dailyindependencenig.com/2015/01/urgent-need-prisonreforms-nigeria/> accessed 12 September, 2015.

68 A medical officer in relation to a prison is a person directed under section 12 of the Prisons Act to perform the functions of medical officer in respect of that prison. See section 18 of the Prisons Act.

69 Section 8(1) of the Prisons Act. 
may be necessary as a result of the conditions occasioned by the prison facility. ${ }^{70}$ The European Committee for the Prevention of Torture has stated that even in the face of harsh economic reality nothing can relieve the State of the need to provide for the health care of those it has deprived liberty. ${ }^{71}$

The African Charter on Human and Peoples' Rights, which Nigeria is signatory to, also provides that "every individual shall have the right to enjoy the best attainable state of physical and mental health." 72 The Charter provides that State parties shall take the necessary steps to protect the health of their citizens and ensure that they receive medical attention when they are sick. In line with these provisions, the government needs to provide basic health facilities to everyone and sundry, including those who have been deprived their liberty through imprisonment. The Nigerian government is not living up to expectation as regards provision of health care for prisoners in Nigeria. According to the National Human Rights Commission Prison Audit Report of 2012, few prisons in Nigeria had hospitals or well-equipped clinics with medical personnel, while some neither had clinics nor hospitals but rather had first aid boxes. In some cases, some prisons had personnel but no health facilities. ${ }^{73}$

\subsection{Right of Safety of Prisoners}

The safety of persons in custody is very important, as this is not an alienable right. It is an obligation of the State to ensure the safety of prisoners in its custody and protect them from any form of violence or ill treatment from the State prison apparatus or other inmates. The international instruments for the protection of rights do not directly impose positive obligation on the State to ensure the safety of prisoners; however, extensive interpretation of the instruments would require the States to offer such protection..$^{74}$ For instance, article $10 \$ 1$ of the United Nations International Covenant on Civil and Political Rights (ICCPR) provides that "all persons deprived of their liberty shall be treated with

70 Andrew Coyle, “A Human Rights Approach to Prison Management” (2002) A Handbook for Prison Staff, International Centre for Prison Studies 49.

71 ibid.

72 Article 16(2) of the Charter.

73 See the Executive Summary of 2012 Prison Audit Report (n 8).

74 Piet Hein van Kempen, "Positive Obligations to Ensure the Human Rights of Prisoners” 26. 
humanity and with respect for the inherent dignity of human person". ${ }^{75}$

Article 5 of the African Charter on Human and Peoples' Rights equally provides that all forms of exploitation and degradation of man shall be prohibited. Also, it is provided that every individual shall be entitled to respect for his life and the integrity of his person and no one may be arbitrarily deprived of this right. ${ }^{76}$ The Charter also provides that everyone shall have the right to liberty and to the security of his person. ${ }^{77}$

There have been reported cases of prisoners bullying other prisoners in the Nigerian prisons, thereby subjecting the vulnerable ones to degrading treatments, undue punishments, usurpation, death and other dehumanizing conditions. ${ }^{78}$ The question that could be asked is whether when someone is incarcerated his right to human dignity has been totally eroded? It can be argued that since it is the law court that can order the condition or the type of punishment that can be meted on a prisoner, the prisoner must not be subjected to any other extraneous punishment; doing that will be extra-legal and unlawful. It is, therefore, important that the prison system must be run in a way that the hardened and violent criminals are not put together in the same prison facility with the vulnerable ones and there should be constant surveillance and monitoring of the activities of the prisoners by the prison officers to checkmate the likelihood of dehumanizing treatments of prisoners amongst themselves.

The State must not shirk its responsibility to see to the welfare of the inmates to the extent of ensuring their safety in prison. In a Jamaican case of Daley v. Jamaica, ${ }^{79}$ the State's neglect of the constant complaint of an inmate who was regularly assaulted by other inmates was held to be in breach of article $10 \$ 1$ of the ICCPR. Similarly, the European Court held in the case of Paul E Audrey Edwards v. the United Kingdom that the State has an obligation to take preventive operational measures to protect vulnerable individuals from criminal acts of another individual in appropriate circumstances. ${ }^{80}$ The use of unwarranted force, torture and degrading treatments in all circumstances are prohibited under the law.

75 See also article $6 \$ 1$ of the ICCPR which protects right to life.

76 Article 4 of the African Charter on Human and Peoples' Rights.

77 Article 6 of the Charter.

78 See Akpunne, B. C. (2014) “Access to Basic Needs as Correlate of Desire to Participate in Rehabilitation Programmes among Inmates of Nigerian Prisons, (2004) Vol. 33, No. 1, European Journal of Humanities and Social Sciences, 1796.

79 HRC, View of 31 July 1998, Comm. 750/1997, para 7.6 (Daley v. Jamaica).

80 ECHR, 14 March 2002, Appl. 46477/99, para 54-56. 
Article 7 of the ICCPR, for instance, provides that "no one shall be subjected to torture or to cruel, inhuman or degrading treatment or punishment."

State obligation to ensure the safety of prisoners also includes protecting the life of the prisoner either from being deprived by another or through the commission of suicide. ${ }^{81}$ In the Western States under the European Convention on Human Rights, (ECHR), States authorities are obliged to protect the right to life of everyone in their territory as provide under Article 2 of the ECHR. The European Court of Human Rights has however interpreted Article 2 to have three distinct elements: the negative obligation on the State to desist from causing unlawful death; the positive obligation to take preventive actions in relation to avoiding death; and a positive obligation to appropriately investigate deaths directly or indirectly caused by the actions of negligence of State officials. ${ }^{82}$

The Universal Declaration of Human Rights (UDHR) 1948 provides that "[e]veryone has the right to life, liberty and security of persons." 83 In a similar vein, the International Convention on Civil and Political Rights, 1966, which Nigeria ratified in October 1993, provide that "[e]very human being has inherent right to life. This right shall be protected by law. No one shall be arbitrarily deprived of his life." ${ }^{84}$ To further protect the life of the individual in Nigeria, the Nigerian Constitution guarantees the safety of life of every individual. It provides in Section 33 that:

Every person has a right to life, and no one shall be deprived intentionally of his life, save in execution of the sentence of a court in respect of a criminal offence, which he has been found guilty in Nigeria.

Once a prisoner has been committed to prison the State has the responsibility to ensure the safety of the life of such prisoner so that his life will not be terminated illegally. The State has an obligation to protect prisoners in its custody as the State is directly responsible to the prisoners and must ensure his safety. Accordingly, the State authorities must take

81 Piet Hein van Kempen (n 74) 27.

82 Irish Penal Reform Trust Position Paper 4, Human Rights in Prison, August 2009, p. 6. See also Kelly, M. The Right to Life. A Practical Guide to the European Convention on Human Rights (Belfast: Northern Ireland Human Rights Commission 2005).

83 Article 3 of the UDHR.

84 Article 6(1) of the ICCPR. 
measures within the scope of their powers to prevent risk to the prisoners, which include monitoring of prisoners, regular visit by doctors, assessment and treatment by a psychiatrist, screening of prisoners, segregation of dangerous prisoners, and preventing the use of alcohol and hard drugs. ${ }^{85}$

There is obviously no regulation in the letters and spirit of Nigerian laws relating to the administration of prison where there is any conspicuous control of prisoners from possible risk to one another except where it is provided that there shall be separation of prisoners based on gender and where it is also provided that each sex, where practicable, will be divided into distinct classes as follows: (a) prisoners before trial to be separated from convicted prisoners; (b) juveniles under sixteen years of age; (c) debtors and other non-criminal prisoners to be separated from criminal prisoners. ${ }^{86}$ It would appear that the mere reason for the segregation of the first category of prisoners is to accord some dignity to prisoners still standing trial and not yet convicted. More so, convicted prisoners may be subjected to certain conditions not applicable to prisoners still standing trial. Therefore, for administrative purposes, such prisoner still standing trial may be separated from convicted prisoners. ${ }^{87}$

On the second prong, the separation of prisoners in this category is based on the age of the prisoners. This is because a prisoner under the age of sixteen is still a juvenile and has high expectancy to be reformed; putting such category of prisoners with adult prisoners may likely worsen their situation and make them hardened. Separation based on the third category is merely for dignity purpose and not to protect the weaker prisoners from the difficult ones. It is, therefore, very important if the law can provide in clear terms the separation of prisoners that are vulnerable to danger from the difficult ones. It is equally important that the prison facility must put in place appropriate mechanism for checking violence in prison.

85 Piet Hein van Kempen (n 74) 28.

86 See Regulations 15 and 16 of the Prisons Regulations (Cap. 366 LFN 1990) Prisons Act Cap P29, Laws of the Federation of Nigeria.

87 For instance, Regulation 21 of the Prisons Regulation, op. cit. provides that a criminal before trial may provide himself with food and other necessaries in the same way as a debtor; and if he does not desire to do so, he shall receive the regular prison allowance for food. 


\subsection{Right Not to be Treated with Cruelty}

It should be reiterated that the fact that a person has been confined to prison does not mean he has lost his right to be treated as human being. $\mathrm{He}$, therefore, ought to be free from cruel and unusual punishment from the prison officials. The United States of America's Supreme Court has constantly held that excessive use of force can constitute cruel and unusual punishment when the use of force by prison officials was not "in good faith effort to maintain or restore discipline" but rather is applied "maliciously and sadistically for the very purpose of causing harm." 88 In Gregg v. Georgia, ${ }^{89}$ the court interpreted the phrase "cruel and unusual punishments to include those punishments that were "unnecessary and wanton infliction of pain" or "grossly out of proportion with the severity of the crime."

Ordinarily, a prison official is not to cruelly treat prisoners by applying any form of force to his person, either using any part of his body or through the use of any form of weapon. The Nigerian Prisons Act makes provision for instances when weapons can be used against prisoners and the conditions under which they can be used. Such conditions include to prevent jail break, ${ }^{90}$ or when such prisoner uses violence to the prison officer himself or any other prison officer or any person, or if the prison officer using the weapons has reasonable grounds to believe that he or that other officer or person, as the case may be, is in danger of life or limb or other grievous harm is likely to be caused to him. ${ }^{91}$ Apart from where it is expressly stated by the law and under such conditions as stipulated by the law, prisons official should not unnecessarily inflict pains on the inmates - to do such will be a breach of the prisoners' right to dignity.

\subsection{Right to Family Life and Correspondence}

An incarcerated inmate should not be considered as losing all his affiliations, especially to his family members when in custody. The law

88 Hudson v. McMillian, 503 U.S. 1, 6, 7 (1992).

89428 U.S. 153, 173 (1976).

90 Section 10(1) of the Prisons Act.

91 Section 10(4) of the Prisons Act. See the case of Nemi v. Attorney General of Lagos State (1996) 6 NWLR PT 425, 42. which was based on the right s of condemned criminals to seek redress against inhuman treatment. See also Baruwa v. The State (1996) 7 NWLR PT 460, p.302. 
recognizes that a prisoner should still have contact with his loved ones while still in custody. Article 12 of the UDHR provides that "No one shall be subjected to arbitrary interference with his privacy, family, home or correspondence..." Furthermore, Article 23 of the International Covenant on Civil and Political Rights states: "The family is the natural and fundamental group unit of society and is entitled to protection by society and the state." Right to family life is guaranteed under section 37 of the 1999 Constitution of the Federal Republic of Nigeria by providing in the marginal note for right to private and family life. It states: "the privacy of citizens, their homes, correspondence, telephone conversations and telegraphic communications is ... guaranteed and protected.” It seems from literal interpretation of this provision that the law is only interested in the privacy of the family and not necessarily preventing the sinews binding the family together from breaking or detaching.

When a person is incarcerated and he/she is not given the opportunity for his/her family members to visit him/her in prison, there is likelihood that the cord that binds him/her to his/her family may be severed. It is therefore important that such rights should be protected. The European Court of Human Rights recognizes that a prisoner should not be deprived access to his family members and that the State has the obligation to assist serving prisoners in maintaining contact with their families, which extends to transferring a prisoner to another prison to ensure closeness to his family members. ${ }^{92}$ Going by the philosophy that imprisonment is not meant to punish but for punishment, a prisoner should not be ostracized from his family but must be given the opportunity to have close relationship with his family members to a certain extent.

Right to family contact is guaranteed under Article 12 of the Universal Declaration of Human Rights (UDHR) and it is not taken away by the mere fact that a person is imprisoned but its exercise may be restricted. The right to create and to maintain a family is another right recognized under Article 16 of the UDHR and it is dealt with in different ways by different jurisdictions. In some countries, prisoners are allowed to have intimate relationships with their spouses while in some they may have sexual relationships under very limited conditions. ${ }^{93}$ Furthermore, some

92 IPTR Position Paper 4 (n 10) 8.

93 Andrew Coyle (n 67) 33. Some Western European States, like Denmark, Sweden, the Netherlands and Spain allow prisoners to be visited by their partners for a period of three hours with appropriate facilities in place during which they may have sexual intercourse. 
jurisdictions allow prisoners to have virtually normal relationships for specific periods of time. ${ }^{94}$

It should be echoed that prison administrators have the responsibility to ensure that family relationship must be maintained in prisons. Hence, provision of all level of communications must be maintained based on this principle, and restriction from family members must not be used as a punishment under any circumstances. ${ }^{95}$ This principle should, therefore, influence the decision of the State to send convicts to a prison near their home, which will facilitate the visit of their family members to the prison. Where a prisoner is kept in a prison far away from home, prison visit can have serious financial implications on the family members, especially the indigent ones; and therefore depriving the affected prisoner the right to his/her family. In addition to visitation of family members and friends to prisons, it is equally important that prisoners are allowed to send and receive correspondence and access to make telephone calls as freely as possible, though subject to the mechanisms of control and surveillance of prisoners and their activities.

The European Court of Human Right has set some standards in ensuring the rights to private life and freedom of correspondence. First, the court states that correspondence between a prisoner and his or her legal representative is a privilege that prison staff or officials or any prison authorities whatsoever should not have access to read. ${ }^{96}$ The court also states that in as much as the prison administrators have the responsibility of ensuring that no contrabands are concealed in the correspondence received by a prisoner, such correspondence must be opened in the presence of the prisoner and must not be read by the prison administrators without the consent of such prisoner. ${ }^{97}$ Right to privacy and correspondence should still remain a right that a prisoner should enjoy despite the fact that he is put in legal custody. Breaching such right by prison administrators is tantamount to depriving the prisoners one of his fundamental rights.

The Nigerian situation is somewhat at variance with the standards derivable from the developed climes. There seems to be no clear evidence

94 ibid.

95 ibid 95.

96 See Campbell v. United Kingdom (1992) Application No. 13590/88). <http:// hudoc.echr.coe.int/sites/eng/pages/search.aspx?>

97 ibid. 
that a prisoner in Nigeria has absolute freedom to receive visitor in private as against a situation where there would be provision for privacy between prisoners and his or her visitor, with beddings or some comforts provided. ${ }^{98}$ Regulation 42 of the Nigerian Prisons Regulations, ${ }^{99}$ only allow convicted prisoners to receive visit from friends in the presence of a prisoner officer. The Regulation equally allows such prisoners to write and receive letters at the discretion of the superintendent. ${ }^{100}$

Regulation 45 allows all other prisoners other than the convicted prisoners all reasonable opportunities daily of communicating with their friends or legal adviser, and they may write and receive letters. The provision of Regulation 45 curtails the right of prisoners to freely associate with friend and to have ample opportunity to communicate with his legal adviser as a result of his conviction. It has been reported that right to even receive visitors by other categories of prisoners in Nigeria is not without some constraints as the prison officers often demand for bribe from the inmates to allow them have contact with their visitors. ${ }^{101}$

\subsection{Right to Fair Treatment in Disciplinary Proceedings and Punishment}

The right to fair hearing is a fundamental right that does not stop to exist the moment a prisoner is put in confinement or custody. A prisoner continues to enjoy this right in the course of the administration of the prison by the State. There are certain rules and regulations that guide the operations of the prisons, which the prisoner as well as the prison staff ought to countenance. There are also disciplinary procedure and punishment put in place in case of breach of any of these rules and regulations. It is pertinent that the prisoners must get fair treatment when being arraigned for any breach of the rules and regulations of the prison. The prisoner who is being charged under a disciplinary proceeding has a right to know the charge levelled against him in advance and the person who made the charge. ${ }^{102}$ The prisoner must be charged without delay,

98 Possibly for the duo to satisfy their sexual desires.

99 Prison Regulations (n 83).

100 ibid.

101 Chukwudi, F (n 3) 39.

102 Rule 30 of the Standard Minimum Rules for the Treatment of Prisoners (approved by the United Nations in 1957) states that "(1) No prisoner shall be punished in accordance with the terms of such law or regulation... (2) No prisoner shall be punished unless he has been informed of the offence alleged against him and given a proper opportunity of presenting his defence...” 
especially when the prisoner is held in isolation or being put under any condition as a pre-trial measure; and must be given the opportunity to prepare his defence. It is equally important that competent and impartial authority should hear the case. In some jurisdictions, independent magistrates or specialist judges are appointed to hear prison disciplinary matters. ${ }^{103}$

In making his defence, the prisoner must be allowed to participate in the proceedings and must be given the opportunity to question the staff or person making the charge against him. The prisoner must also be allowed to call any person to assist him, provided he is not able to defend himself; and in a case where the possible punishment may be severe, he may be assisted with legal practitioner to defend him. ${ }^{104}$ There must also be opportunity for the prisoner to appeal to higher authority in case he is not satisfied with the judgment of the disciplinary panel.

Punishment for prisoners found guilty of the charges levied against him must be commensurate with the offence, and must not be excessive. Certain forms of punishments are specifically prohibited and rated as inhuman and degrading and should not be meted out on prisoners found guilty of any offence in prison. The Standard Minimum Rules for the Treatment of Prisoners ${ }^{105}$ provides that "corporal punishment, ${ }^{106}$ punishment by placing in a dark cell, and all cruel, inhuman or degrading punishments shall be completely prohibited as punishment for disciplinary offences." ${ }^{107}$ The Standard Minimum Rules also states further that:

1. Punishment by close confinement or reduction of diet shall never be inflicted unless the medical officer has examined the prisoner and certified in writing that he is fit to sustain it.

103 Andrew Coyle (n 67) 77.

104 ibid.

105 Thereafter referred to as SMR. These Rules were adopted by the First United Nations Congress on the Prevention of Crime and Treatment of Offenders, held at Geneva in 1955, and approved by the Economic and Social Council by its Resolutions 663 C (XXIV) of 31 July, 1957 and 2076 (LXII) of 13 May, 1977. Available at <www.ohchr.org/Documents/ProfessionalInterest/ treatmentprisoners.pdf $>$ accessed June 21, 2015.

106 Note that corporal punishment (whipping with cane) is still a form of punishment for prison offence under the Nigerian Law. See regulation 49(1) (iv) of the Nigerian Prisons Regulations (n 83).

107 Rule 31 of the Standard Minimum Rules for the Treatment of Prisoners. 
2. The same shall apply to any other punishment that may be prejudicial to the physical or mental health of a prisoner. In no case may such punishment be contrary to or depart from the principle stated in rule 31 .

3. The medical officer shall visit daily prisoners undergoing such punishment and shall advise the director (of Prison) if he considers the termination or alteration of the punishment necessary on grounds of physical or mental health. ${ }^{108}$

The above restrictions on punishment have found expression in legal provisions encouraging the protection of the rights of prisoners. The European community, for instance, has adopted these provisions, which are reflected in the European Prison Rules. ${ }^{109}$ Accordingly, punishments may include a formal warning, forfeiture of wages (where these are paid for prison work), restriction from participating in recreational activities, restrictions on the use of certain personal possessions, restriction of movement in the prison, forfeiture of right to remission of sentence, and such lighter punishments proportionate to the offences. ${ }^{110} \mathrm{It}$ is submitted that these should be a minimum standard for restriction of certain punishment of prisoners that should be adopted in all jurisdictions. As stated above, putting prisoners in solitary confinement as a measure of punishment should be discouraged. It is therefore imperative that the provision of the Regulation 49(3)(a) of the Nigerian Prisons Regulations, which recommends solitary confinement of prisoners for a term not exceeding two weeks as a punishment be reviewed.

\section{CONCLUSION}

As earlier stated in this article, imprisonment is meant to punish and not for punishment. That a person is committed to prison by the court is not to say that he/she as totally lost all he/her rights as a human being. ${ }^{111}$ Therefore, a prisoner should not be subjected to conditions in prison that are dehumanizing or degrading. A prisoner is also entitled to enjoy

108 Rule 32 of the SMR.

109 See Rule 37 of the European Prison Rules.

110 Andrew Coyle (n 67) 79.

111 See for example, Rule 2of the European Prison Rules (2006), which provides that "persons deprived of their liberty retain all rights that are not lawfully taken away by the decision sentencing them or remanding them in custody.” 
basic rights that free persons enjoy, which are not taken away by the pronouncement of the court during his committal to prison. The Kampala Declaration on Prison Conditions in Africa (1996) stipulates that "prisoners should retain all rights which are not expressly taken away by the fact of their detention." "112 It is now realized that the fact that someone is imprisoned would not make him less of a human being and he should not be treated thus. The United Nations Human Committee in its General Comment No. 21, said in relation to the treatment of persons deprived of their liberty that "respect for the dignity of such persons must be guaranteed under the same conditions as for that of free persons." Free persons enjoy certain rights and same rights should be accorded the prisoners if not legally taken away.

The basic rights that prisoners should enjoy, as a bare minimum, while in prison have been carefully x-rayed in this article. Such rights include right to vote, right of safety of prisoners, right to health, right to family life and correspondence, right not to be treated with cruelty, right to fair treatment in disciplinary proceedings and punishment, and by extension, right of the children of prisoners. All these rights, without being exhaustive, are very germane to the welfare of prisoners. The African Commission on Human and Peoples' Rights in its "Resolution on Prisons in Africa" states that "the rights established and guaranteed under the African Charter on Human and People's Rights extend to all categories of persons including prisoners, detainees and other persons deprived of their liberty". ${ }^{113}$

In view of the above, it is essential for government administrators in charge of prisons to prevent overcrowding of prison facilities and while the government should develop policies that would address poor physical and health conditions of prisoners. Policies should also be developed to prevent inhuman treatment of prisoners, prevention of death in custody, and also ensure prompt implementation of such policies. Furthermore, there should be adequate mechanism in place for investigating death of prisoners in custody.

In addition, prisoners should be given opportunity to have regular contact with friends and family, as isolation from human contact,

112 Second Recommendation, Kampala Declaration on Prison Conditions in Africa (1996) adopted at the International Seminar on Prison Conditions in Africa, 19 to 21 September, 1996.

113 African Commission on Human and Peoples' Rights, Resolution 19(XVII) 95 "Resolution on Prisons in Africa”, 13-22 March 1995. 
especially of loved ones, may cause serious psychological pains on the prisoners. ${ }^{114}$ It is also important that the government should put machinery in place for proper implementation of policies and regulations that positively impact on the welfare of prisoners. If the proper thing is done, it would be better for the society because prisoners who complete their prison terms with wounded psyche will unleash evil on the society and, therefore, constitute more danger to the society than before. Prison sentence should reform rather than deform prisoners.

In order to progressively realize and improve the administration of prison system and the conditions of prisoners in Nigeria a number of practical measures must be put in place. Firstly, a Commission should be established to oversee the prison system in Nigeria for the purpose of ensuring that the prisons in Nigeria attain the set minimum international standard. As at today, the prison system is under the regulation of the Ministry of Interior in Nigeria, which is saddled with a lot of responsibilities. These include granting of Nigerian citizenship; consular and immigration services; granting of business permits and expatriate quotas; co-ordination of national/independence day celebrations; reforming and reintegration of inmates; management of national emergencies; recruitment of officers and men of the Prison Service, Immigration Service, Fire Service and the Nigerian security and Civil Defence Corp; and managing the retirement of retirees of Parliamentary Services under its supervision. ${ }^{115}$ With the volume of work this Ministry is engaged in, it is important that a separate commission be established which will adequately focus on the prison system in Nigeria with the hope of improving its standard, and thus improve the standard of treatment of prisoners in Nigeria. ${ }^{116}$ Such a commission should have its spread across the states in Nigeria, for effectiveness. There must be regular

114 Lobel Jules, "Prolonged Solitary Confinement and the Constitution", Legal Studies Research Paper Series, Working Paper No. 2009-19, July 2009, University of Pittsburgh School of Law, Pittsburgh, Pennsylvania. Journal of Constitutional Law, Vol. 11:1, p. 138. < http://sssrn.com/abstract=1428922 > accessed 20 May 2015.

115 <http://interior.gov.ng/index.php/the-ministry/articles> The Official Website of the Ministry of Interior accessed 28 August 2015.

116 Establishment of such a commission was proposed by the Senator Abubakar Danso Sodangi (Nasarawa West) in 2006, by a bill titled "Nigerian Prison Service Commission (Establishment, etc) Bill, 2006" but has not seen the light of the day. 
visit by the commission to prisons to assess the prisons and prisoners' conditions. ${ }^{117}$

There is also a need to establish a prison-reporting scheme applicable in all the prisons in Nigeria to enable the prisoners to air their grievances. Therefore, a neutral body should be set up to hear the grievances of the prisoners and to recommend appropriate steps to be taken to redress such complaints or impose sanctions in case of erring persons. Furthermore, there is need to build more prisons to augment the existing ones to alleviate the problem of prison congestion. The government should also take proactive steps to improve the condition of prisons in Nigeria and provide adequate facilities for the upkeep and health needs of prisoners.

Similarly, there is also a need to decentralize the prison system. The prisons fall under the exclusive legislative list in the Nigerian

117 Though section 11 of the Nigerian Prisons Act provides for the appointment of visitors to the prisons, and also certain ex-officio as visitors, there is conflicting powers given to the Minister of Internal Affairs and the Director of Nigerian Prisons Service to appoint visitors to the prisons as the section provides in subsection (2) that the Minister, after consultation with the State Authority, may in respect of any prison appoint such persons as he thinks fit to be visitors or members of a visiting committee. Subsection (3) of that section also provides that the Director may authorize such persons as he thinks fit to be voluntary visitors in respect of any prison or prisons. There is also no provision as to the number, term of office and qualifications of the members of the Committees (except the ex-officio who are serving judicial officers) and their modus operandi, which can lead to the visitors working at cross purposes. The functions of the visiting committee include Inspecting the several wards, cells, solitary or punishment cells, and other apartments or divisions of the prison; hearing the complaints (if any) of the prisoners; inspection of the journals, registers, and books of the prison, and calling the attention of the superintendent of the prison to any irregularity in carrying out the prison regulations, or in the discipline or behaviour of the officers, or any fault in the buildings which may appear to require attention, and examining into and giving directions respecting any cause of complaint stated by any prisoner (see Regulation 143, Prisons Regulations). Moreover, Regulation 146 of the Prisons Regulations 146 provides that each committee shall at the end of every year, and at such times as the Minister may direct, make a report in writing to the Minister as to the general state and management of the prison under its charge, accompanied by such recommendations as the committee may think proper. With this laudable effort, little has been done to improve the prisons conditions in Nigeria possibly due to the concentration of many responsibilities in the Ministry of Interior that oversees the prisons. It is therefore important that a separate Commission be established to oversee the prisons affairs. 
Constitution ${ }^{118}$ and, therefore, it is a matter under the federal government jurisdiction. It is important to note that not all the prisoners in Nigeria are confined to prisons due to breach of the federal laws alone, but also the state laws. It is, therefore, imperative that the states should also be given the opportunity to establish prisons and run the affairs of such prisons. This will reduce the financial burden on the federal government. However, there will have to be a constitutional amendment for this to be possible.

Furthermore, a mechanism for taking disciplinary measures and imposing legal sanctions on prisons officials who maltreat prisoners should also be established. It is equally important to promote a policy that requires the separation of prisoners with lesser offences or the vulnerable ones from the hardened criminals. Finally, to lessen congestion of prisons, it is also important to adopt community service as an alternative to imprisonment for lesser offences.

118 See Item 48, Part I, Second Schedule of the 1999 Constitution of the Federal Republic of Nigeria (as amended). 